\title{
MULTI LAYER PERCEPTRON DAN PRINCIPAL COMPONENT ANALYSIS UNTUK DIAGNOSA KANKER PAYUDARA
}

\author{
Made Satria Wibawa ${ }^{1, a}$, I Md. Dendi Maysanjaya ${ }^{2, b}$ \\ 1 \\ Sistem Komputer, STMIK STIKOM Bali, Bali, Indonesia - 80226 \\ ${ }^{2}$ Pendidikan Teknik Informatika, Universitas Pendidikan Ganesha, Bali, Indonesia - 81116 \\ e-mail: satria.wibawa@stikom-bali.ac.id ${ }^{a}$, dendi.ms@undiksha.ac.id ${ }^{b}$
}

\begin{abstract}
Abstrak
CAD (Computer Aided Diagnosis) merupakan teknik diagnosa berbantuan komputer untuk meningkatkan akurasi hasil diagnosa dari suatu penyakit. CAD telah banyak digunakan untuk diagnosa dari berbagai penyakit, khususnya penyakit kanker payudara. Multi layer perceptron (MLP) sebagai salah metode dari jaringan saraf tiruan telah banyak digunakan untuk klasifikasi kanker payudara. Penelitian ini bertujuan untuk mencari kombinasi parameter paling optimal untuk mendiagnosa kanker payudara. Kombinasi parameter tersebut juga diujikan dengan metode reduksi fitur Principal Component Analysis (PCA). Hasil penelitian menunjukkan bahwa parameter paling optimal adalah fungsi optimisasi RELU serta TANH dengan fitur optimisasi adam dengan tingkat akurasi 0.974 .
\end{abstract}

Kata kunci: CAD, kanker payudara, MLP, PCA, RELU, TANH, adam

\begin{abstract}
CAD (Computer Aided Diagnosis) is a computer-aided diagnosis techniques used to improve the accuracy diagnosis disease result. CAD has been widely used for diagnosis of various diseases, especially cancer of the breast. Multi layer perceptron (MLP) as the method of artificial neural network has been widely used for classification of breast cancer. This research aims to find the most optimal combinations of parameters to diagnose breast cancer. The combination of these parameters were also examined by the method of reduction of Principal Component feature Analysis (PCA). The results showed that the most optimal parameter is a function WITHIN a RELU optimization and optimization feature adam 0973 accuracy.
\end{abstract}

Keywords : CAD, breast cancer, MLP, PCA, RELU, TANH, adam

\section{PENDAHULUAN}

Jaringan syaraf tiruan (artificial neural network) telah menjadi salah satu metode yang sering digunakan pada proses klasifikasi. Banyaknya penelitian di bidang klasifikasi menggunakan jaringan syaraf tiruan menjanjikan metode ini dapat dipilih sebagai alternatif untuk mengganti metode klasifikasi konvensional(1)(2).

Jaringan syaraf tiruan memiliki beberapa kelebihan dibandingkan metode klasifikasi konvensional lainnya. Yang pertama, jaringan syaraf tiruan merupakan metode yang mengadaptasikan dirinya dengan data, sehingga tidak diperlukan adanya spesifikasi bentuk fungsional dan distribusional model yang eksplisit. Kedua, jaringan syaraf tiruan fungsi universal untuk memperkirakan hubungan antar keanggotaan kelas dengan atribut dari objek. Ketiga, jaringan syaraf tiruan umumnya lebih reliabel terhadap noise dalam data. Yang terakhir, jaringan syaraf tiruan mampu menghitung nilai probabilitas posterior, yang merupakan dasar untuk membangun aturan klasifikasi dan analisis statistika. Salah satu metode dalam jaringan syaraf tiruan yang luas digunakan adalah multilayer perceptron (MLP). MLP telah banyak diterapkan untuk berbagai bidang, salah satunya adalah bidang kesehatan, terutama diagnosa penyakit kanker(3). 
Kanker merupakan salah satu penyebab utama morbiditas dan kematian di seluruh dunia dengan angka mencapai 14 juta lebih kasus. Kanker merupakan penyebab kematian nomor dua di seluruh dunia dan pada tahun 2015 angka kematian karena kanker mencapai 8,8 juta lebih. Secara global, penyebab 1 dari 6 kematian adalah penyakit kanker (4). Beberapa jenis kanker yang paling umum ditemui adalah kanker paru-paru, hati (liver), perut dan payudara. Kanker payudara merupakan penyakit kanker dengan persentase kasus baru tertinggi, yaitu $43,3 \%$ dan persentase kematian akibat kanker payudara sebesar 12,9\%(5).

Menurut World Health Organization (WHO), deteksi dini dapat meningkatkan peluang penanganan yang sukses dalam kasus penyakit kanker. Diagnosa kanker payudara dapat dilakukan dengan cara biopsi atau metode screening. Metode screening meliputi pemeriksaan fisik, MRI, dan mamografi. Jika hasil screening inkonklusif, maka biopsi melalui analisa mikroskopis seperti Fine Needle Aspiration (FNA) dapat digunakan untuk menentukan hasil diagnosa. Biopsi merupakan cara

\section{METODE}

Metode memberikan penjelasan tentang langkah-langkah, data, lokasi penelitian, metode evaluasi yang digunakan serta penjelasan terstruktur tentang algoritma atau metode dari penelitian yang dibahas.

1. Data

Klasifikasi yang dilakukan adalah klasifikasi biner dengan kelas tumor jinak (benign) dan tumor ganas (malignant). Jumlah data yang digunakan adalah sebanyak 569 data dengan 357 data kelas benign dan 212 kelas malignant(8). Fitur merupakan properti pengukuran terhadap suatu proses/objek yang sedang diamati. Berdasarkan kumpulan fitur tersebut, metode machine learning dapat melakukan klasifikasi. Fitur biasanya disusun oleh ahli di domain dimana machine learning diterapkan. Pada penelitian ini, fitur yang digunakan adalah beberapa parameter yang paling definitif dalam diagnosa kanker payudara diantara metode diagnosis lainnya(6).

Untuk membantu dalam diagnosa penyakit kanker khususnya kanker payudara, Computer-Aided Diagnosis (CAD) dapat digunakan. CAD telah secara luas digunakan untuk mendeteksi dan diagnosa dalam kanker payudara. Oleh karena itu, peningkatan kinerja dari CAD dalam bentuk akurasi, sensitivitas dan spesifisitas telah menjadi salah satu bidang riset yang paling utama dan penting. Kelebihan utama dalam penerapan penggunaan komputer untuk membantu diagnosis medis terletak pada pengolahan data mining yang mampu mengekstrak pola tertentu dari data. Diagnosis dengan bantuan komputer jika dilakukan dengan penanganan yang tepat memiliki potensi untuk menangkap keahlian interpretasi dari seorang pakar. Sehingga dapat meningkatkan akurasi diagnosis dan tingkat keyakinan seorang pakar(7).

Penelitian ini bertujuan untuk melakukan diagnosa kanker payudara menggunakan CAD dengan metode MLP.

pengukuran citra jaringan sel tumor yang diambil dari proses FNA.

Penjelasan mengenai fitur dapat dilihat pada Tabel I. Terdapat 10 pengukuran tekstur dan kontur yang diambil dari citra FNA. Sepuluh fitur tersebut adalah radius, texture, perimeter, area, smoothness, compactness, concavity, concave points, symmetry, fractal dimension. Dari 10 utama tersebut diambil lagi 3 ciri statistiknya, yaitu rerata, standar deviasi dan nilai terbesar, sehingga total fitur berjumlah 30 buah.

Jumlah fitur yang dimiliki oleh dataset tersebut cukup banyak. Mengingat semakin banyaknya jumlah fitur, maka jumlah neuron pada neural network akan semakin banyak. Hal ini akan menyebabkan penghitungan bobot yang semakin banyak dan membutuhkan waktu yang lama untuk mencapai konvergensi. Karena itu diperlukan suatu teknik untuk mengurangi/mereduksi fitur agar waktu 
komputasi pada saat training menjadi lebih sedikit. Selain itu, fitur yang banyak juga belum tentu dapat memberikan kontribusi terhadap klasifikasi yang maksimal.

\begin{tabular}{|c|c|c|c|}
\hline \multicolumn{4}{|c|}{ Tabel 1. Fitur Data } \\
\hline NO & FITUR & KETERANGAN & TIPE DATA \\
\hline 1 & Radius & $\begin{array}{l}\text { Jarak rata-rata dari titik } \\
\text { pusat citra ke } \\
\text { perimeter }\end{array}$ & Real \\
\hline 2 & Texture & $\begin{array}{l}\text { Standar deviasi dari } \\
\text { nilai keabuan pada } \\
\text { citra }\end{array}$ & Real \\
\hline 3 & Perimeter & $\begin{array}{l}\text { Panjang dari garis tepi } \\
\text { pada sel }\end{array}$ & Real \\
\hline 4 & Area & $\begin{array}{l}\text { Luas dari penampang } \\
\text { sel }\end{array}$ & Real \\
\hline 5 & Smoothness & $\begin{array}{l}\text { Variasi lokal pada } \\
\text { panjang radius }\end{array}$ & Real \\
\hline 6 & Compactness & $\frac{\text { perimeter }^{2}}{\text { area }}-1.0$ & Real \\
\hline 7 & Concavity & $\begin{array}{l}\text { Banyaknya bagian } \\
\text { concave pada kontur } \\
\text { sel }\end{array}$ & Real \\
\hline 8 & Concave points & $\begin{array}{l}\text { Jumlah bagian yang } \\
\text { concave pada kontur } \\
\text { sel }\end{array}$ & Real \\
\hline 9 & Symmetry & $\begin{array}{l}\text { Tingkat kesamaan } \\
\text { belahan sisi kanan dan } \\
\text { kiri sel }\end{array}$ & Real \\
\hline 10 & Fractal dimension & $\begin{array}{l}\text { Rasio kompleksitas } \\
\text { dari sebuah pola }\end{array}$ & Real \\
\hline
\end{tabular}

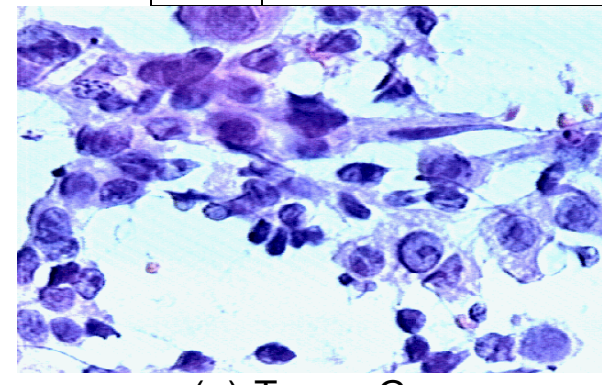

(a) Tumor Ganas

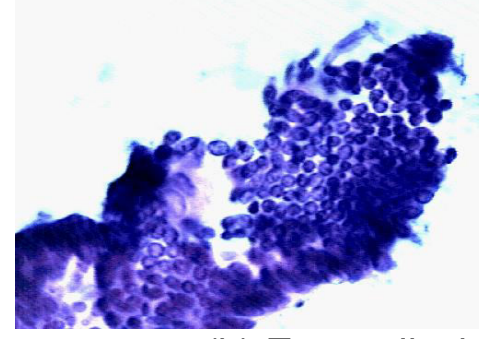

(b) Tumor Jinak

Gambar 1. Contoh Citra Tumor Payudara FNA

Contoh citra tumor payudara ganas dapat dilihat pada Gambar 1a, sedangkan untuk tumor payudara jinak dapat dilihat pada Gambar 1b. 
2. PCA

Principal Component Analysis (PCA) merupakan salah satu teknik untuk mereduksi dimensi dari suatu data. Tidak seperti metode seleksi fitur yang mengurangi jumlah fitur dengan cara menghilangkan fitur yang dianggap tidak penting tanpa membentuk fitur baru, PCA mengurangi dimensi data dengan cara 'mengkombinasikan' intisari dari atribut dengan membentuk alternatif subset fitur yang lebih kecil.

Jadi, pada metode PCA terbentuk fitur yang baru. Jumlah principal component dapat berkisar 1-n, dimana $n$ adalah jumlah fitur. Namun, tentu saja jumlah principal component sebaiknya paling banyak sebesar $n-1$, karena tujuan awal adalah untuk mengurangi waktu komputasi (9)(10)(11).

\section{MLP}

Multilayer Perceptron atau yang biasa disingkat MLP adalah salah satu jenis dari feed-forward neural network dengan satu atau lebih hidden layer. Pada umumnya MLP terdiri dari layer input yang merupakan kumpulan neuron untuk memasukkan data; minimal satu hidden layer sebagai neuron komputasi dan layer ouput sebagai neuron penampung hasil komputasi.

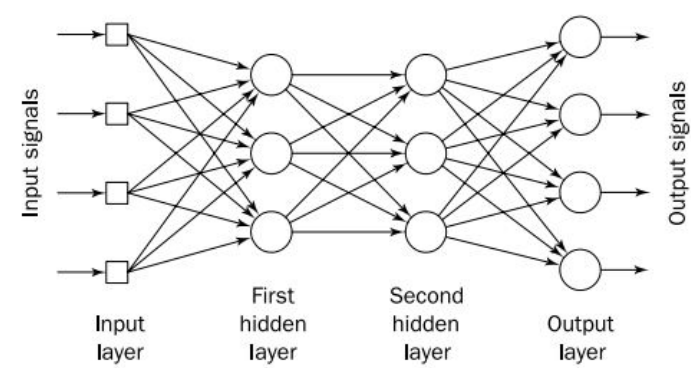

Gambar 2 Arsitektur MLP Standar

Dalam MLP, terdapat dua parameter penting yaitu fungsi aktivasi dan fungsi optimisasi. Fungsi aktivasi menentukan output pada sebuah node dari beberapa elemen input. Sedangkan fungsi optimisasi berfungsi untuk menentukan bobot paling tepat sesuai dengan input dan output.
Pada penelitian ini, terdapat dua buah fungsi aktivasi dan tiga buah fungsi optimisasi yang diujikan. Kedua fungsi aktivasi itu adalah Rectified Linear Unit (RELU) dan fungsi aktivasi Hyperbolic Tangent Function (TANH). Sedangkan untuk ketiga fungsi optimisasi yang digunakan adalah fungsi Limited-memory Broyden-Fletcher-Goldfarb-Shanno (LBFGS), Stochastic Gradient Descent (SGD) dan Adam.

Fungsi aktivasi Rectified Linear Unit (RELU) merupakan fungsi aktivasi yang memiliki perhitungan yang sederhana. Proses forward dan backward dengan RELU menggunakan kondisi if. Tidak ada operasi eksponensial, perkalian atau pembagian pada RELU. Jika elemen bernilai negatif, maka nilainya di-set menjadi 0 . Cara perhitungan yang sederhana seperti itu membuat memiliki waktu komputasi yang relatif sedikit pada saat proses training dan testing.

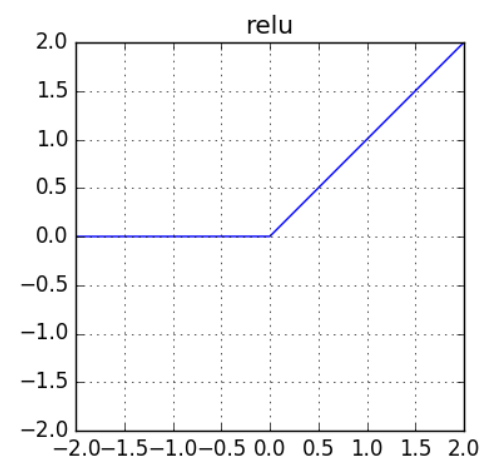

Gambar 3 Grafik Fungsi ReLU

\begin{tabular}{ccc}
\multicolumn{2}{c}{ Fungsi aktivasi } & Hyperbolic \\
Tangent Function (TANH) & umumnya
\end{tabular} memiliki performa yang lebih baik dibandingkan fungsi aktivasi sigmoid dan logistic. Hal ini dikarenakan fungsi TANH dapat mencapai konvergensi lebih cepat dibandingkan fungsi sigmoid dan logistic. Performa fungsi TANH hampir sama dengan performa fungsi RELU. 


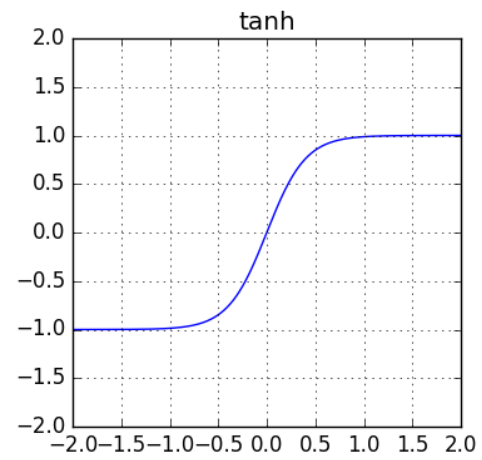

Gambar 4 Grafik Fungsi TANH

Sama seperti metode optimasi lainnya, Stochastic Gradient Descent bertujuan untuk mencari global minima dari cost function. Fungsi optimisasi Limitedmemory Broyden-Fletcher-GoldfarbShanno atau disingkat L-BFGS termasuk ke dalan metode quasi-Newton yang menggunakan algoritma BFGS. Disebut limited karena menggunakan komputer memori yang terbatas. Karena metode Newton sulit dan memerlukan waktu komputasi yang lama maka dikembangkanlah L-BFGS yang memiliki keunggulan dimana L-BFGS memerlukan memori yang lebih sedikit.

\section{HASIL DAN PEMBAHASAN}

Nilasi akurasi dari semua skema klasifikasi MLP dengan seleksi fitur PCA dapat dilihat secara lengkap pada Tabel II dan pergerakan nilai terhadap perubahan jumlah dimensi PCA dapat dilihat pada Gambar 5.

Nilai akurasi tertinggi yang dicapai per skema klasifikasi diberi tanda kuning, sedangkan nilai akurasi terendah diberi tanda merah. Pada metode ReLU \& SGD, akurasi tertinggi yang dicapai adalah 0.854 , sedangkan nilai akurasi terendah adalah 0.744. Akurasi tertinggi pada metode ini dicapai pada saat penggunaan 2 dimensi PCA, sedangkan akurasi terendah diperoleh saat menggunakan 7 dimensi PCA.

ReLU dan L-BFGS mencapai akurasi tertinggi saat menggunakan 10 dimensi PCA, nilai akurasi yang diperoleh adalah 0.967. Akurasi terendah diperoleh saat menggunakan 1 dimensi PCA, yaitu dengan nilai 0.932 .

Akurasi tertinggi yang dicapai dengan metode ReLU \& Adam adalah 0.974 dengan penggunaan 8 dimensi PCA. Sama dengan ReLU \& L-BFGS, nilai akurasi terendah diperoleh saat menggunakan 1 dimensi PCA. Nilai akurasi terendah yang diperoleh adalah 0.932 .

Metode TANH \& L-BFGS menghasilkan akurasi dengan rentang diatas 0.800 , namun tidak mencapai 0.9 . Akurasi tertinggi yang dicapai adalah 0.886 dengan penggunaan 5 dimensi PCA. Sedangkan untuk akurasi terendah diperoleh saat penggunaan 20 dimensi PCA, dengan nilai sebesar 0.830 .

TANH dan L-BGS rata-rata memberikan nilai akurasi di atas 0.9. Akurasi tertinggi dicapai saat penggunaan 14 dimensi PCA, yaitu dengan akurasi sebesar 0.968. Akurasi terendah diperoleh saat penggunaan 1 dimensi, yaitu dengan nilai sebesar 0.933 .

Metode terakhir, yaitu TANH \& Adam, menghasilkan akurasi tertinggi sebesar 0.974. Akurasi tertinggi tersebut dicapai saat penggunaan 8 dimensi PCA. Akurasi terendah yang dicapai sangat jauh berbeda dibandingkan akurasi tertinggi. Akurasi terendah diperoleh saat penggunaan 23 dimensi PCA, dengan nilai sebesar 0.765 .

Tabel II Nilai Akurasi pada Setiap Skema Klasifikasi

\begin{tabular}{|c|c|c|c|c|c|c|}
\hline $\begin{array}{c}\text { JUMLAH } \\
\text { DIMENSI } \\
\text { PCA }\end{array}$ & $\begin{array}{c}\text { ReLU \& } \\
\text { SGD }\end{array}$ & $\begin{array}{c}\text { ReLU \& } \\
\text { L-BFGS }\end{array}$ & $\begin{array}{c}\text { ReLU \& } \\
\text { Adam }\end{array}$ & $\begin{array}{c}\text { TANH \& } \\
\text { SGD }\end{array}$ & $\begin{array}{c}\text { TANH \& } \\
\text { L-BFGS }\end{array}$ & $\begin{array}{c}\text { TANH \& } \\
\text { Adam }\end{array}$ \\
\hline 1 & 0.809 & 0.932 & 0.932 & 0.860 & 0.933 & 0.932 \\
\hline 2 & 0.854 & 0.942 & 0.946 & 0.874 & 0.947 & 0.944 \\
\hline 3 & 0.821 & 0.945 & 0.954 & 0.863 & 0.939 & 0.960 \\
\hline
\end{tabular}




\begin{tabular}{|c|c|c|c|c|c|c|}
\hline $\begin{array}{c}\text { JUMLAH } \\
\text { DIMENSI } \\
\text { PCA }\end{array}$ & $\begin{array}{c}\text { ReLU \& } \\
\text { SGD }\end{array}$ & $\begin{array}{c}\text { ReLU \& } \\
\text { L-BFGS }\end{array}$ & $\begin{array}{c}\text { ReLU \& } \\
\text { Adam }\end{array}$ & $\begin{array}{c}\text { TANH \& } \\
\text { SGD }\end{array}$ & $\begin{array}{c}\text { TANH \&-BFGS } \\
\text { L-BANH \& }\end{array}$ & $\begin{array}{c}\text { TANam } \\
\text { Ada }\end{array}$ \\
\hline 4 & 0.844 & 0.954 & 0.965 & 0.874 & 0.937 & 0.965 \\
\hline 5 & 0.846 & 0.963 & 0.967 & 0.886 & 0.956 & 0.965 \\
\hline 6 & 0.831 & 0.944 & 0.965 & 0.874 & 0.944 & 0.965 \\
\hline 7 & 0.744 & 0.965 & 0.972 & 0.835 & 0.967 & 0.968 \\
\hline 8 & 0.830 & 0.958 & 0.974 & 0.877 & 0.963 & 0.974 \\
\hline 9 & 0.837 & 0.952 & 0.974 & 0.854 & 0.956 & 0.974 \\
\hline 10 & 0.775 & 0.967 & 0.974 & 0.858 & 0.965 & 0.968 \\
\hline 11 & 0.809 & 0.954 & 0.968 & 0.863 & 0.967 & 0.968 \\
\hline 12 & 0.789 & 0.967 & 0.972 & 0.847 & 0.961 & 0.970 \\
\hline 13 & 0.830 & 0.960 & 0.967 & 0.872 & 0.960 & 0.968 \\
\hline 14 & 0.833 & 0.961 & 0.967 & 0.865 & 0.968 & 0.968 \\
\hline 15 & 0.830 & 0.951 & 0.970 & 0.860 & 0.958 & 0.967 \\
\hline 16 & 0.810 & 0.963 & 0.970 & 0.875 & 0.961 & 0.965 \\
\hline 17 & 0.842 & 0.956 & 0.968 & 0.847 & 0.963 & 0.970 \\
\hline 18 & 0.816 & 0.960 & 0.974 & 0.854 & 0.963 & 0.974 \\
\hline 19 & 0.844 & 0.965 & 0.970 & 0.868 & 0.960 & 0.968 \\
\hline 20 & 0.768 & 0.967 & 0.958 & 0.830 & 0.963 & 0.961 \\
\hline 21 & 0.795 & 0.956 & 0.967 & 0.849 & 0.961 & 0.965 \\
\hline 22 & 0.810 & 0.958 & 0.965 & 0.858 & 0.958 & 0.961 \\
\hline 23 & 0.802 & 0.953 & 0.963 & 0.858 & 0.961 & 0.765 \\
\hline 24 & 0.788 & 0.960 & 0.965 & 0.858 & 0.963 & 0.965 \\
\hline 25 & 0.782 & 0.961 & 0.968 & 0.844 & 0.961 & 0.967 \\
\hline 26 & 0.781 & 0.958 & 0.967 & 0.842 & 0.963 & 0.967 \\
\hline 27 & 0.828 & 0.956 & 0.963 & 0.860 & 0.958 & 0.963 \\
\hline 28 & 0.831 & 0.947 & 0.967 & 0.868 & 0.956 & 0.965 \\
\hline 29 & 0.758 & 0.954 & 0.963 & 0.847 & 0.961 & 0.963 \\
\hline
\end{tabular}

Seperti yang terlihat pada Tabel II, nilai akurasi tertinggi diperoleh pada metode ReLU \& Adam. Nilai tertinggi tersebut sebesar 0.974 dan dicapai saat menggunakan 8 dimensi PCA. Akurasi terendah di antara semua metode diperoleh pada penggunaan metode ReLU \& SGD. Nilai terendah yang diperoleh adalah 0.744 pada penggunaan 7 dimensi PCA.

Jika dilihat dari pola nilai akurasi yang terbentuk, fungsi optimasi SGD memberikan hasil yang relatif lebih rendah dibandingkan L-BFGS dan Adam pada kedua fungsi aktivasi ReLU dan TANH.

Gambar 5 menjelaskan pengaruh jumlah dimensi terhadap nilai akurasi keenam metode klasifikasi. Skema ReLU \& SGD, ReLU \& L-BFGS, ReLU \& Adam, TANH \& SGD, TANH \& L-BFGS dan TANH \& Adam secara berturut-turut digambarkan pada Gambar 5(a), (b), (c), (d), (e) dan (f). Jika dilihat dari pergerakan grafik, nilai akurasi skema klasifikasi pada Gambar (a), (b) dan (d) fluktuatif. Tidak ada pola naik atau turun, penambahan atau pengurangan jumlah dimensi PCA tidak berhubungan dengan nilai akurasi. Sedangkan pada Gambar (c) dan (d) nilai akurasi rata-rata cenderung bergerak naik seiring penambahan jumlah dimensi PCA. Sedangkan pada Gambar 5(f), yaitu metode TANH \& Adam, nilai akurasi hanya 


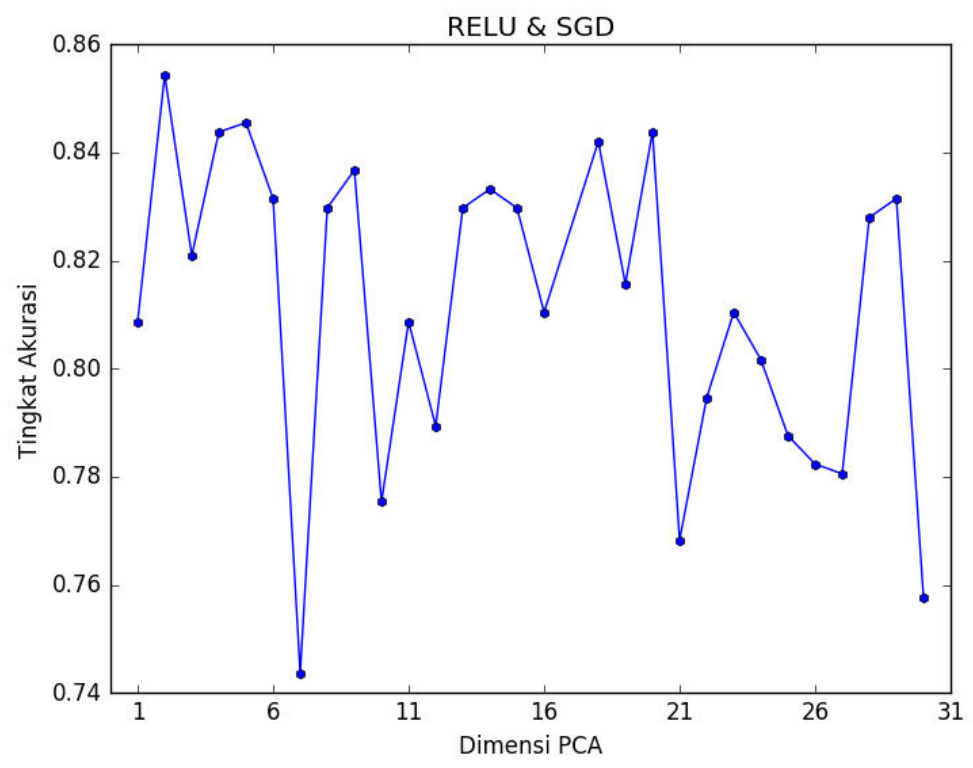

(a)

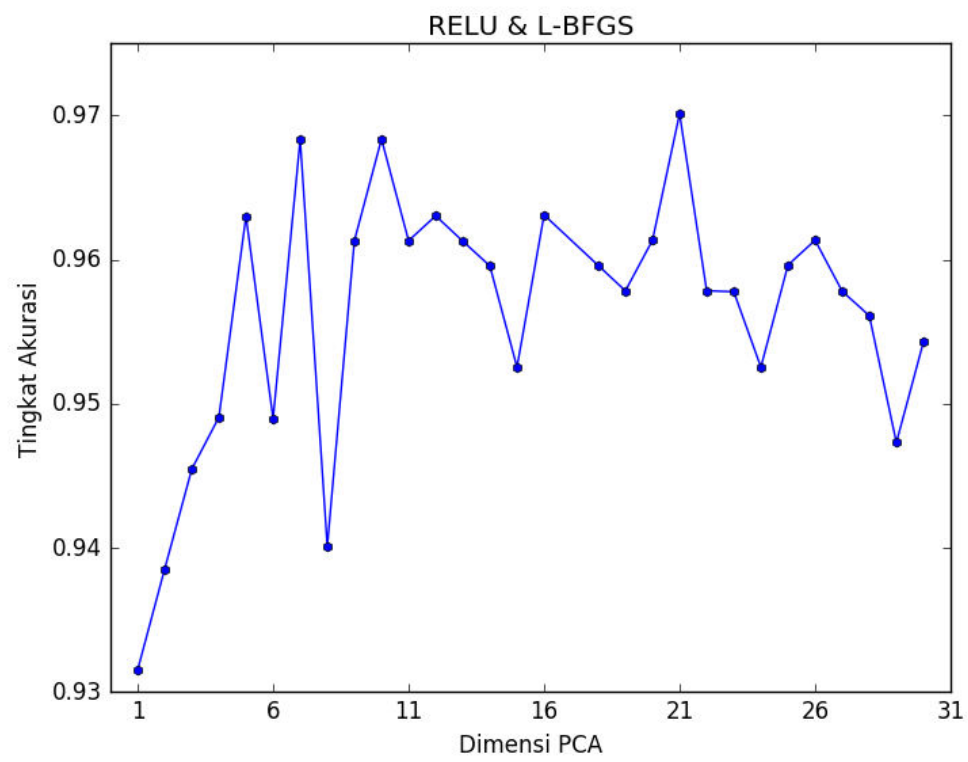

(b) 


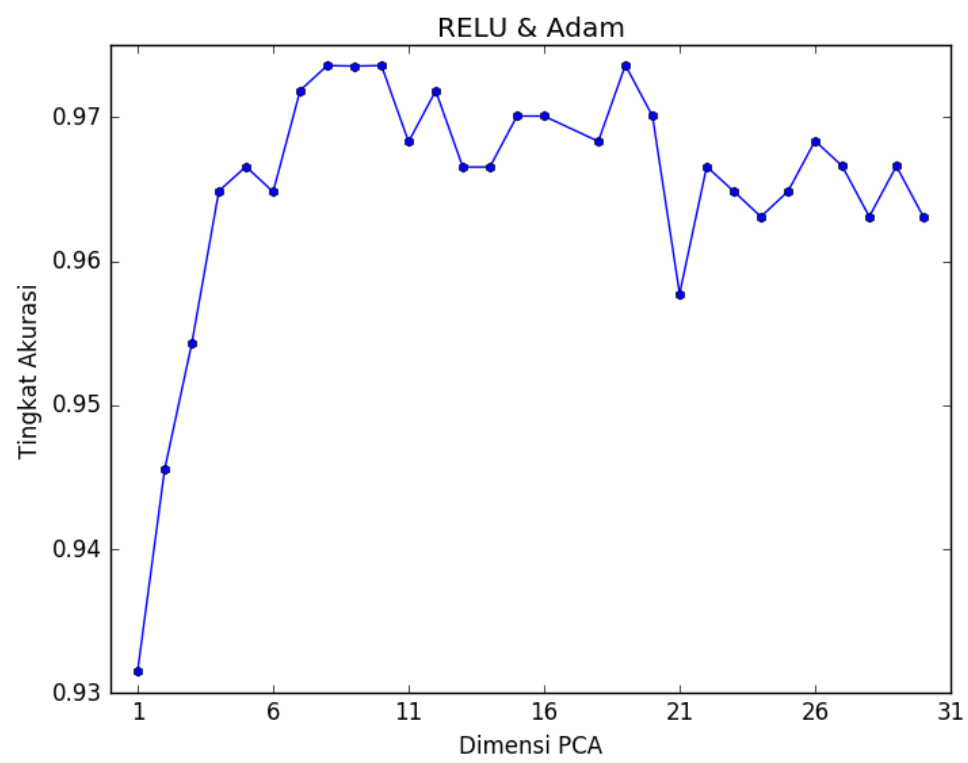

(c)

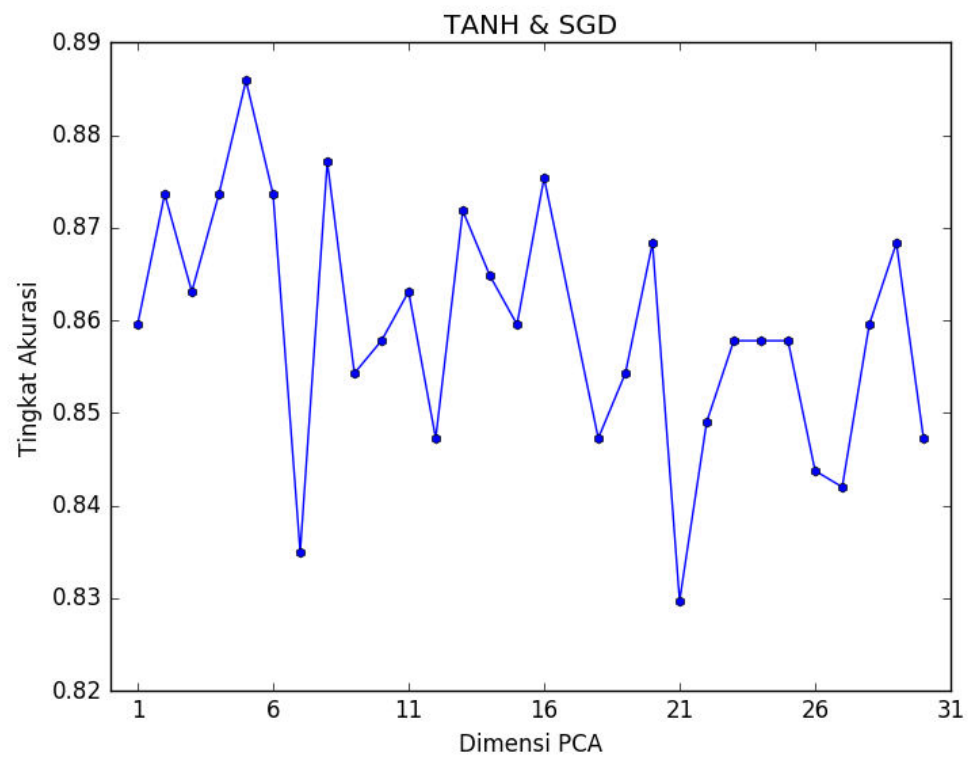

(d) 


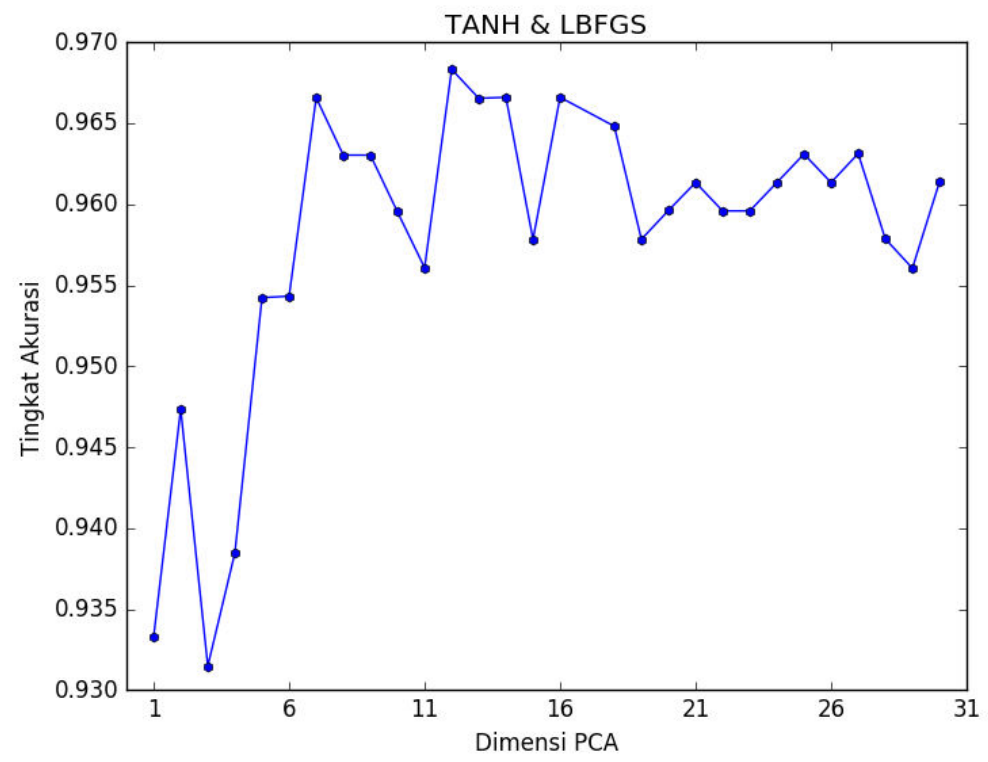

(e)

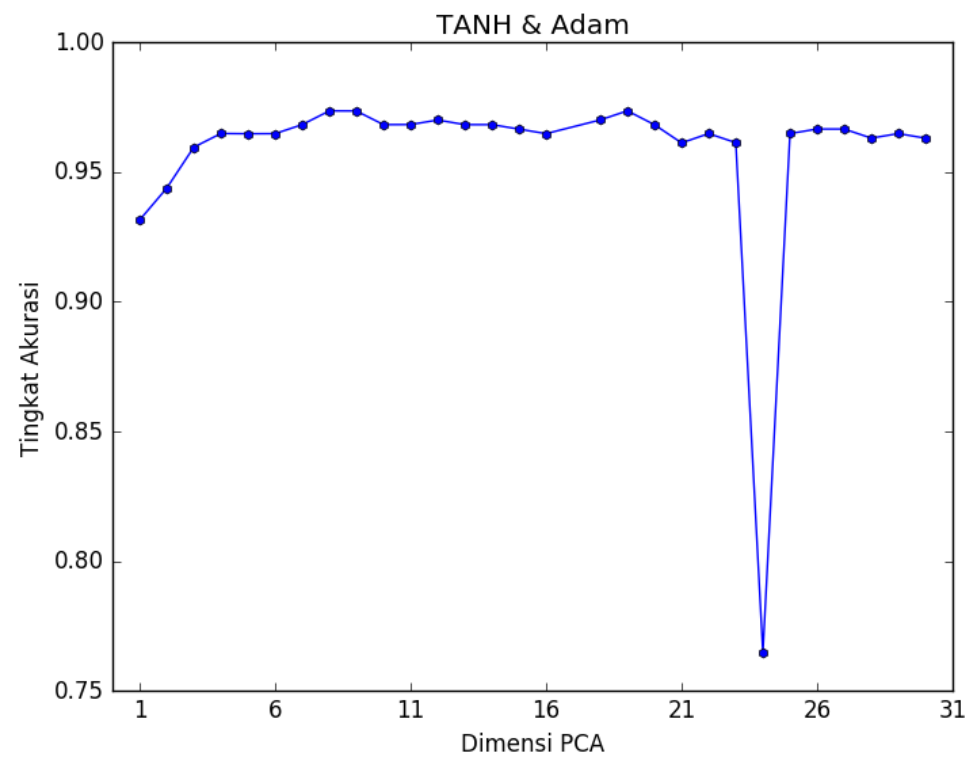

(f)

Gambar 5 Grafik Pengaruh PCA Terhadap Akurasi Metode (a)ReLU \& SGD, (b)ReLU \& LBFGS, (c)TANH \& SGD, (d)TANH \& L-BFGS, (e) TANH \& Adam

\section{SIMPULAN}

Penelitian ini bertujuan untuk mendiagnosa penyakit kanker payudara dengan diagnose berbantuan computer (Computer Aided Diagnosis). Metode yang digunakan adalah MLP sebagai klasifier dan PCA sebagai metode reduksi fitur. Kombinasi fungsi aktivasi, fungsi optimisasi dan jumlah dimensi PCA diteliti untuk menentukan kombinasi optimal dari ketiga parameter tersebut. Adapun fungsi aktivasi yang diujikan adalah RELU dan TANH, sedangkan fungsi optimisasi yang diujikan adalah SGD, Adam dan L-BFGS. Untuk rentang jumlah dimensi PCA yang digunakan adalah 1-30. Hasil eksperimen menunjukkan bahwa kombinasi antara fungsi aktivasi RELU dengan metode optimisasi adam dan kombinasi antara fungsi aktivasi TANH dengan metode 
optimisasi adam menghasilkan tingkat akurasi tertinggi, yaitu dengan tingkat akurasi 0.974 .

Penelitian ke depannya dapat memanfaatkan data dari modalitas lainnya untuk melakukan CAD pada kanker payudara

\section{REFERENSI}

1. Negnevitsky M. Artificial intelligence: a guide to intelligent systems. 2nd ed. Harlow, England; New York: AddisonWesley; 2005. $415 \mathrm{hlm}$.

2. Kshirsagar $\mathrm{P}$, Rathod N. Artificial neural network. Int J Comput Appl. 2012;

3. Seidel $P$, Seidel A, Herbarth $O$. Multilayer perceptron tumour diagnosis based on chromatography analysis of urinary nucleosides. Neural Netw. 2007;20(5):646-651.

4. Ganpisetti R, Chandluri $P$, Lakshmi B, Swami PA. WORLD JOURNAL OF PHARMACEUTICAL AND MEDICAL RESEARCH.

5. Ferlay J, Héry C, Autier P, Sankaranarayanan R. Global burden of breast cancer. Dalam: Breast cancer epidemiology. Springer; 2010. hlm. 119.

6. Jeleń ILukasz, Fevens T, Krzyżak A. Classification of breast cancer malignancy using cytological images of fine needle aspiration biopsies. Int $\mathrm{J}$ Appl Math Comput Sci. 2008;18(1):7583.

7. Doi K. Computer-aided diagnosis in medical imaging: historical review, current status and future potential. Comput Med Imaging Graph. 2007;31(4):198-211.

8. Lichman M. UCl Machine Learning Repository [Internet]. University of California, Irvine, School of Information and Computer Sciences; 2013.
Tersedia

pada:

http://archive.ics.uci.edu/ml

9. Bro R, Smilde AK. Principal component analysis. Anal

2014;6(9):2812-2831.

10. Awada W, Khoshgoftaar TM, Dittman D, Wald R, Napolitano A. A review of the stability of feature selection techniques for bioinformatics data. Dalam: Information Reuse and Integration (IRI), 2012 IEEE 13th International Conference on. IEEE; 2012. hlm. 356363.

11. Janecek A, Gansterer W, Demel M, Ecker $\mathrm{G}$. On the relationship between feature selection and classification accuracy. Dalam: New Challenges for Feature Selection in Data Mining and Knowledge Discovery. 2008. hlm. 90105. 